U.S. Department of the Interior

U.S. Geological Survey

Prepared in cooperation with the

PUERTO RICO ELECTRIC AND POWER AUTHORITY

\title{
Sedimentation Survey of Lago Yahuecas, Puerto Rico, March 1997
}

U.S. GEOLOGICAL SURVEY Water-Resources Investigations Report 98-4259 


\section{Sedimentation Survey of Lago Yahuecas, Puerto Rico, March 1997}

By Luis R. Soler-López, Richard M.T. Webb, and Francisco Pérez-Blair

Water-Resources Investigations Report 98-4259

In cooperation with the

PUERTO RICO ELECTRIC AND POWER AUTHORITY

San Juan, Puerto Rico: 1999 


\section{U.S. DEPARTMENT OF THE INTERIOR \\ BRUCE BABBITT, Secretary}

\section{U.S. GEOLOGICAL SURVEY}

Charles G. Groat, Director

Use of trade names in this report is for identification purposes only and does not imply endorsement by the U.S. Government.

For additional information write to:

Copies of this report can be purchased from:

District Chief

U.S. Geological Survey

GSA Center, Suite 400-15

U.S. Geological Survey

651 Federal Drive

Branch of Information Services

Box 25286

Guaynabo, Puerto Rico 00965-5703

Denver, CO 80225-0286 


\section{CONTENTS}

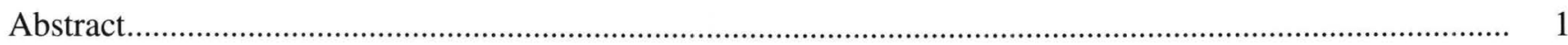

Introduction

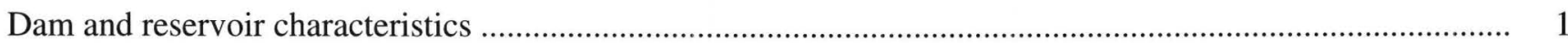

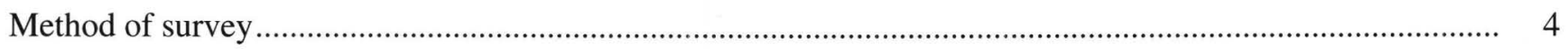

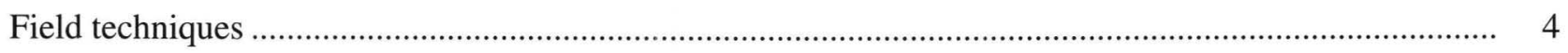

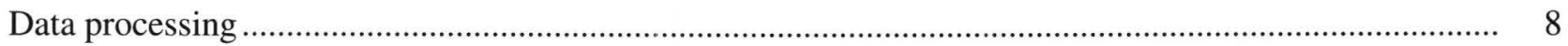

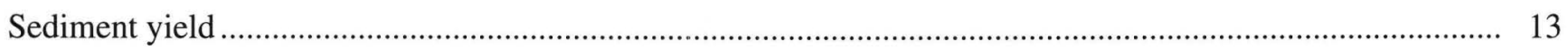

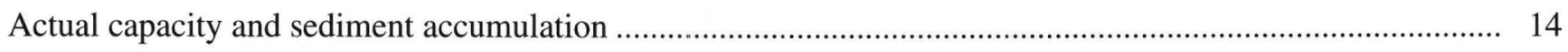

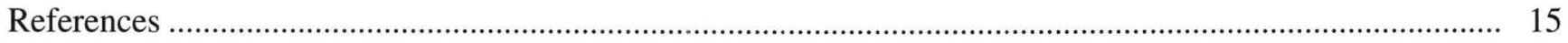

\section{PLATES}

[Plates are in pocket]

1. Lago Yahuecas, Puerto Rico, Bathymetry, March 1997

2. Lago Yahuecas, Puerto Rico, Bathymetry, 1956 


\section{FIGURES}

1.-4. Map showing:

1. Location of Lago Yahuecas in the Río Grande de Añasco basin, Puerto Rico

2. Planned cross-section locations for the 1997 bathymetric survey of Lago Yahuecas, Puerto Rico.

3. Reference distances for longitudinal profiles of Lago Yahuecas, Puerto Rico, during the March 1997 bathymetric survey.

4. Track lines and sediment core locations of the 1997 bathymetric survey of Lago Yahuecas, Puerto Rico

5. Selected cross sections generated from TIN surface model of Lago Yahuecas, Puerto Rico, for 1956 and 1997

6. Comparison of longitudinal profiles for 1956 and 1997 along the thalweg of Lago Yahuecas, Puerto Rico

7. Graph showing the relation between pool elevation and volume derived from the 1956 and 1997 TIN surface models of Lago Yahuecas, Puerto Rico

\section{TABLES}

1. Principal characteristics of Lago Yahuecas and dam as of 1997

2. Summary of the average dry bulk density of the sediment cores collected on Lago Yahuecas, Puerto Rico, March 1997

3. Summary data for prior and current sedimentation surveys of Lago Yahuecas, Puerto Rico 


\begin{tabular}{rll}
\hline Multiply & By & To obtain \\
millimeter & Length & inch \\
centimeter & 25.4 & foot \\
meter & 0.032808 & foot \\
kilometer & 3.2808 & mile \\
& 0.62137 & \\
square meter & Area & square foot \\
square kilometer & 10.7639 & square mile \\
square kilometer & 0.3861 & acre \\
& 247.11 & \\
cubic meter & Volume & cubic foot \\
million cubic meters & 35.315 & acre-foot \\
cubic meter & 810.7 & acre-foot \\
& Volume per unit time (includes flow) & \\
cubic meter per second & 35.315 & cubic foot per second \\
cubic meter per second & 15,850 & gallon per minute \\
cubic meter per second & 22.826 & million gallons per day \\
gram per cubic centimeter & Mass per area (includes sediment yield) & \\
megagram per square kilometer & 62.428 & pound per cubic foot \\
\hline
\end{tabular}

Horizontal Datum - Puerto Rico Datum, 1940 Adjustment

Sea level: In this report, "sea level" refers to the National Geodetic Vertical Datum of 1929 (NGVD of 1929)—a geodetic datum derived from a general adjustment of the first-order level nets of both the United States and Canada, formerly called "Sea Level Datum of 1929."

\section{Acronyms used in this report:}

$\begin{array}{ll}\text { BLASS } & \text { Bathymetric/Land Survey System } \\ \text { DGPS } & \text { Differential Global Positioning System } \\ \text { GIS } & \text { Geographic Information System } \\ \text { GPS } & \text { Global Positioning System } \\ \text { PREPA } & \text { Puerto Rico Electric and Power Authority } \\ \text { TIN } & \text { Triangulated Irregular Network } \\ \text { USGS } & \text { U.S. Geological Survey }\end{array}$

\section{Translations}

$\begin{array}{ll}\text { Spanish } & \text { English } \\ \text { Lago } & \text { Lake } \\ \text { Río } & \text { River }\end{array}$





\title{
Sedimentation Survey of Lago Yahuecas, Puerto Rico, March 1997
}

\author{
By Luis R. Soler-López, Richard M.T. Webb, and Francisco Pérez-Blair
}

\section{Abstract}

Sediment is filling Lago Yahuecas, a reservoir built to divert water to Lago Guayo for power generation, at an average rate of 2 percent per year. During March 10 to 13, 1997, the U.S. Geological Survey conducted a bathymetric survey of Lago Yahuecas to determine the amount of sediment deposited and sedimentation rate in the reservoir. Also, reservoir sediments were cored and sampled to determine the dry bulk density. Over the last 41 years, the storage capacity of the reservoir has been reduced by approximately 81 percent from 1.76 million cubic meters in 1956 to 0.33 million cubic meters in 1997. The average annual storage capacity loss to sediment deposition in the reservoir is 34,878 cubic meters per year. The average dry bulk density of the sediment samples was 0.98 gram per cubic centimeter. Based on the contributing drainage area of 45.17 square kilometers, the average sediment yield of the basin was estimated to be 757 megagrams per square kilometer per year.

\section{INTRODUCTION}

The U.S. Geological Survey (USGS) in cooperation with the Puerto Rico Electric and Power Authority (PREPA) conducted a sedimentation survey to determine the current storage capacity of Lago Yahuecas, the storage loss due to sedimentation, and the location of areas of greatest sediment deposition within the reservoir. These data will be useful in evaluating the feasibility of dredging the lake to increase its capacity. To accomplish the objectives, a bathymetric survey of Lago Yahuecas was conducted on March 10 to 13, 1997. Data on position and water depths were simultaneously acquired with a differential global positioning system (DGPS) and a depth sounder and then directly stored in digital form. The digitized data were transferred into a geographic information system (GIS) for processing and analysis. The GIS was then used to calculate storage volumes and sediment accumulation by comparing the 1956 topographic contour map with the 1997 bathymetric survey. Also, sediment cores were collected at eight sites in the reservoir to determine the dry bulk density and to estimate the sediment yield of the reservoir basin.

\section{DAM AND RESERVOIR CHARACTERISTICS}

The construction of the Lago Yahuecas dam was finished in 1956. Lago Yahuecas is part of the Southwestern Puerto Rico Project of the Puerto Rico Water Resources Authority (Sheda and Legas, 1968); the dam diverts water to the Lago Guayo. The dam is located on the Río Blanco, approximately 6.44 kilometers northwest of the town of Adjuntas (fig. 1) and was built to provide about 2 million cubic meters of water for hydroelectric power generation and cropland irrigation. The contributing drainage area of Lago Yahuecas at the dam is 45.17 square kilometers. 


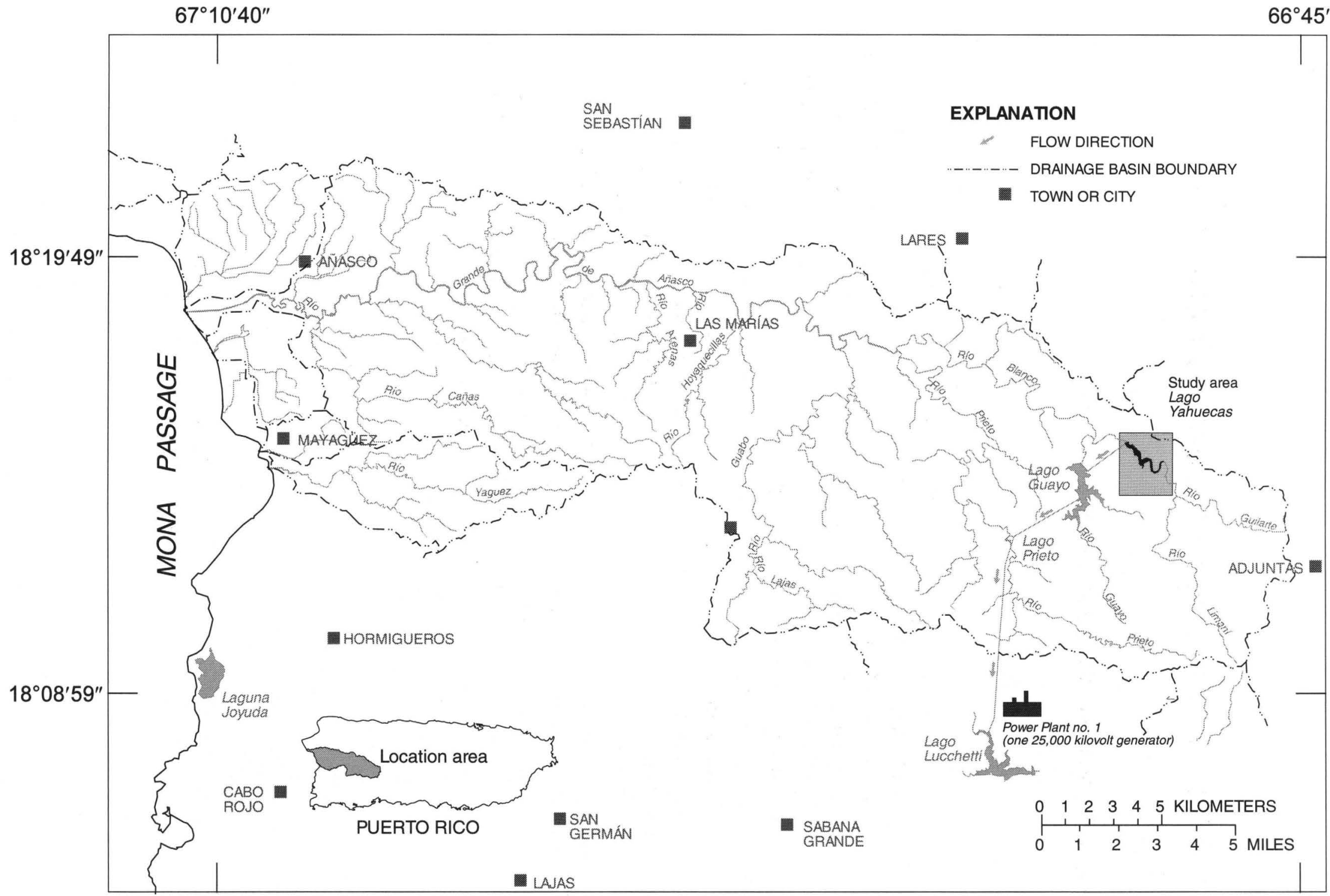

Figure 1. Location of Lago Yahuecas in the Río Grande de Añasco basin, Puerto Rico. 
The Lago Yahuecas dam consists of a concrete gravity structure with a length of 137.16 meters, a maximum structural height of 27.43 meters, and a maximum base width of 18.3 meters. The 60.96- meter-long spillway is an ungated overflow type, centrally located, capable of managing an inflow design flood of 1,102 cubic meters per second. The elevation at the top of the spillway crest is 448.36 meters above mean sea level. Water is diverted to Lago Guayo through an unlined diversion tunnel located at the west side of the reservoir and approximately 91.4 meters upstream from the spillway. The diversion tunnel is 1,972 meters long and has a diameter of 3.35 meters (Sheda and Legas, 1968). The principal characteristics of Lago Yahuecas and dam are listed in table 1.

Table 1. Principal characteristics of Lago Yahuecas and dam as of 1997 (Sheda and Legas, 1968)

[All elevations are in meters above mean sea level]

Total length of dam at top (spillway and nonoverflow sections) 137.16 meters

Length of spillway section 60.96 meters

Elevation of crest of spillway 448.36 meters

Maximum width at base 18.3 meters

Normal volume at spillway elevation ${ }^{1}$ 2.2 million cubic meters

1956 volume at spillway elevation ${ }^{2}$ 1.76 million cubic meters

Maximum Volume .2 .96 million cubic meters

Design discharge over the spillway at a head of 3.96 meters (elevation 452.32 meters) 1,102 cubic meters per second 1997 spillway crest-level storage. 0.33 million cubic meters

Drainage area at dam site. 45.17 square kilometers

Maximum structural height 27.43 meters

Maximum original depth of normal pool. 22.77 meters

Maximum depth during 1997 survey 6.50 meters

\footnotetext{
${ }^{1}$ Original reported capacity.

${ }^{2}$ Original volume recomputed using the TIN surface model of the 1956 preimpoundment topography.
} 


\section{METHOD OF SURVEY}

The Lago Yahuecas bathymetric survey involved planning, data acquisition, data processing, and analysis. A geographic information system, Arc/Info, was used to plan the cross-section locations and for the analysis of bathymetric data. Cross-section locations were established at a spacing of 50 meters (fig. 2). Data were acquired with a differential global positioning system combined with a depth sounder. The soundings were subsequently adjusted to represent depths below the spillway elevation (datum 448.36 meters above mean sea level). The corrected depths were then converted to elevations above mean sea level. A bathymetric map of the reservoir bottom was then constructed. The original storage capacity of the reservoir was calculated by digitizing a 1:20,000 scale topographic map and creating a surface of the triangulated irregular network (TIN) model using the GIS. The pool elevation during the three days of the bathymetric survey (March 10 to 13, 1997) remained constant at the spillway elevation of 448.36 meters above mean sea level.

\section{Field Techniques}

Field work was conducted on March 10 to 13, 1997. The bathymetric survey used the bathymetric/ land survey system (BLASS), developed by Specialty Devices, Inc. The system uses two Motorola SixGun DGPS receivers for horizontal positioning of the survey boat. The DGPS units were first used in static survey mode to establish a reference mark at a site overlooking the reservoir. Satellite information was simultaneously recorded at a previously established survey control station HELECHO (USGS lat $18^{\circ} 14^{\prime} 45.370 " N$., long $66^{\circ} 48^{\prime} 41.836 " \mathrm{~W}$.), and two new reference stations (YAH-1 and YAH-2) were established. A 45-minute static global positioning system (GPS) observation session was used to establish the new reference point YAH-1 lat $\left(18^{\circ} 13^{\prime} 02.872^{\prime \prime} \mathrm{N}\right.$., long $66^{\circ} 49^{\prime} 00.315^{\prime \prime}$.) on a hill overlooking the reservoir. Although $\mathrm{YAH}-2$ lat (18 $13^{\circ} 05.859^{\prime \prime} \mathrm{N}$., long $66^{\circ} 49^{\prime} 00.469^{\prime \prime} \mathrm{W}$.) was also established, there was no need to use it because the correction signal from YAH-1 was never lost. Postprocessing, using the program CentiPoint (GPSsoft, Inc.), showed a horizontal error of less than 10 centimeters for YAH-1 assuming station HELECHO had no horizontal error.

Once YAH-1 was established, one DGPS was installed there as the master station and the other DGPS was installed in the survey boat as the mobile unit. The DGPS on board the survey boat independently calculated a position every second while receiving a set of pseudo-range corrections from the master station every 5 seconds to maintain positional precision to within 2 meters. Lake depths were measured using a RAYTHEON DE-719D depth recorder. The depth recorder reports depths to the nearest 0.1 meter and was calibrated in water depths of 3 and 6 meters. The bathymetric survey software HYPACK (Coastal Oceanographics, Inc.) received and recorded the positions and depths once every second while in survey mode. HYPACK runs on a portable personal computer and is used both to record data and to navigate. The helmsman of the survey boat is provided with a graphical display showing the lakeshore, the location of the planned cross sections, the actual position of the boat while underway, and indicators of speed and the amount of deviation from the planned track lines. A total of 60 cross sections at a 50-meter spacing were planned; however, sediment accumulation in the upper reach of the reservoir limited bathymetric data collection to only 31 cross sections. The reference longitudinal distances measured in Lago Yahuecas are shown in figure 3. At distances of more than 500 meters from the dam, data collection was difficult because of sediment accumulation and vegetation growth inside the reservoir. The sediment cores locations and actual track lines where bathymetric data were collected are shown in figure 4 . Bathymetric data were collected from the dam to cross section 26 located approximately 1,400 meters upstream from the dam. At the beginning and end of each day of surveying, the survey boat was secured on a selected site on shore and positional data were recorded for at least 30 seconds to verify the precision of the DGPS-calculated positions. 


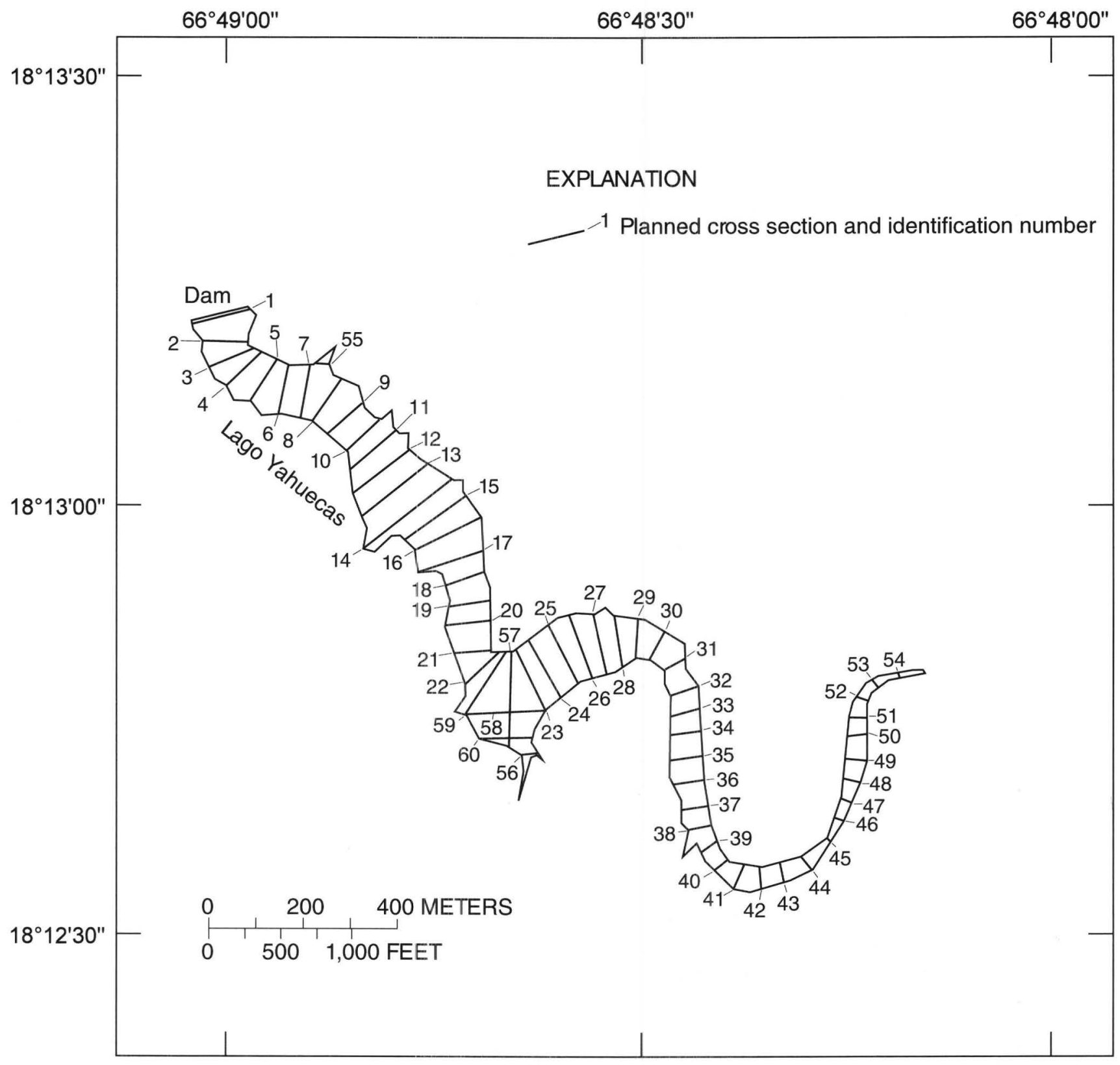

Figure 2. Planned cross-section locations for the 1997 bathymetric survey of Lago Yahuecas, Puerto Rico. 


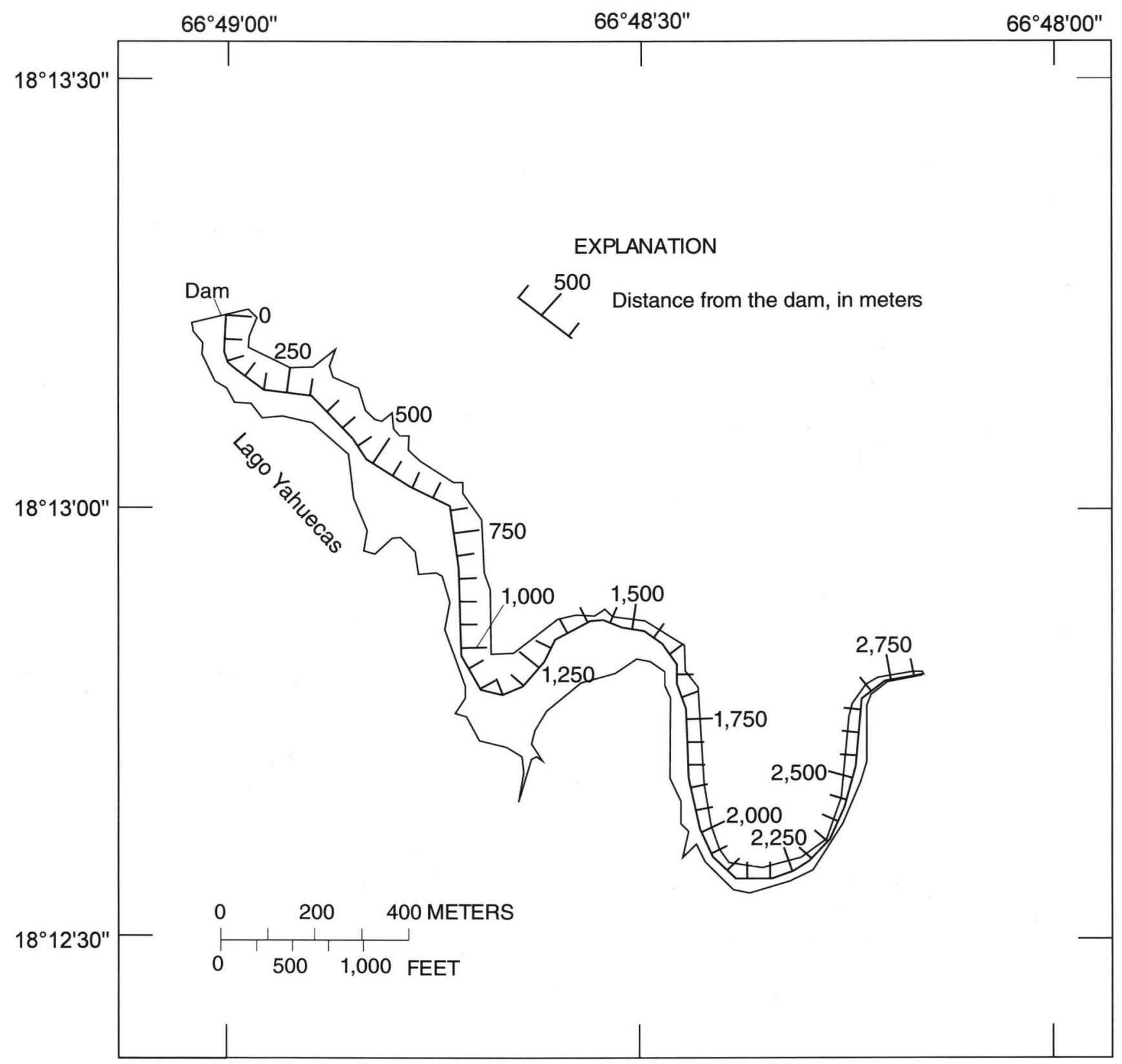

Figure 3. Reference distances for longitudinal profiles of Lago Yahuecas, Puerto Rico, during the March 1997 bathymetric survey. 


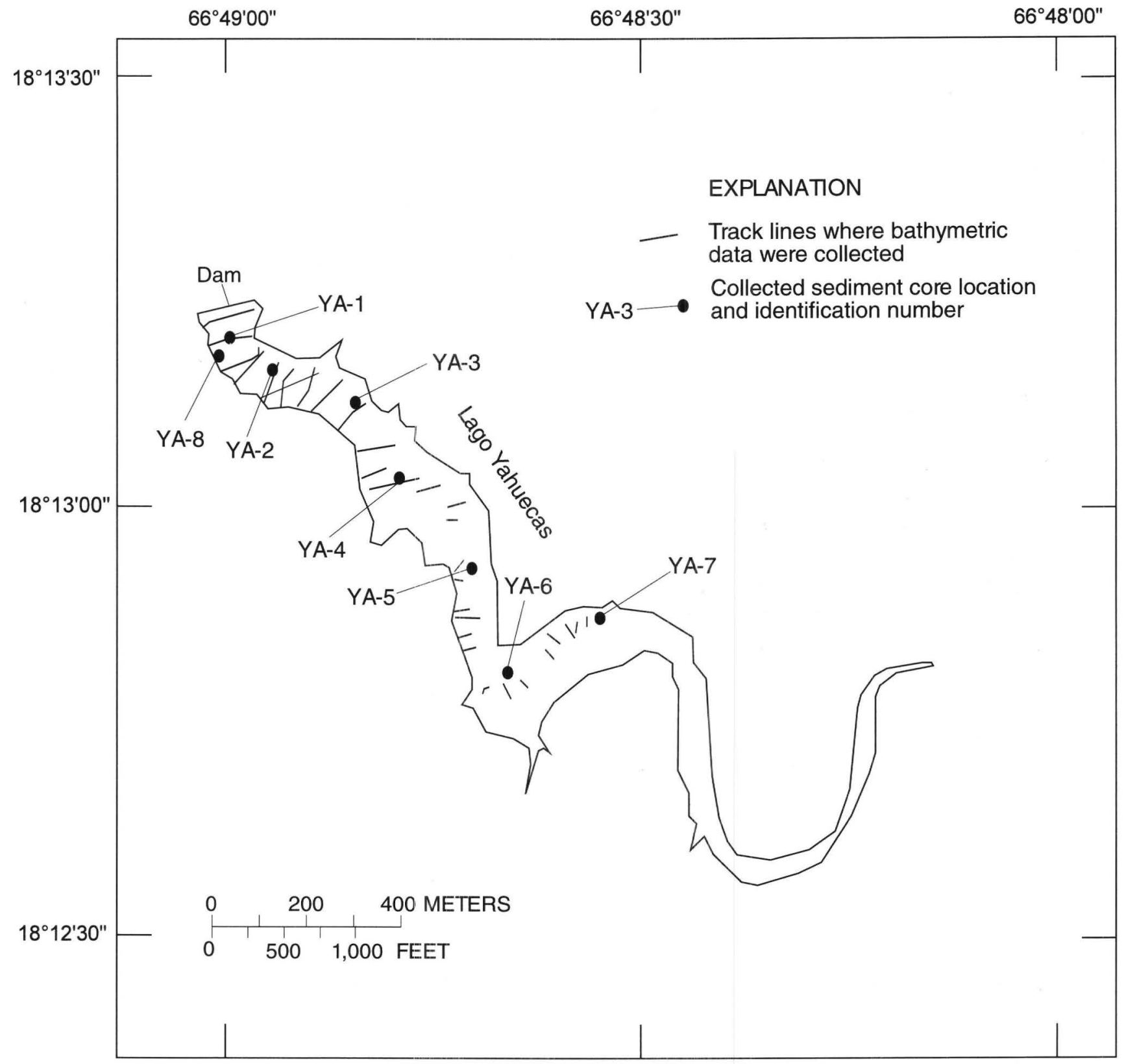

Figure 4. Track lines and sediment core locations of the 1997 bathymetric survey of Lago Yahuecas, Puerto Rico. 
Random errors can appear in positional data because of GPS calculation errors. Also, errors in depth data can occur because of bubbles obstructing the transducer face or because insufficient fathometer signal gain. Physical or electronic problems encountered in the field were corrected as soon as they were detected. If the section of missing or bad data extended more than 20 meters, that cross section was rerun. If the amount of erroneous data occurred for less than 20 meters along the cross section, and the reservoir bottom exhibited no change in slope before and after the location in which data were lost, the section was not rerun but the data file was flagged for later editing.

\section{Data Processing}

Initial editing and verification of the positional and depth data were performed within the HYPACK program. Sounding positions were corrected to eliminate anomalous spikes. Spikes or jumps in the positional data may occur when reception of the satellite's signal is obstructed by local topographic features or disrupted by electromagnetic interference. In such instances, the sounding location may be erroneously calculated several hundred meters from the actual position one second before or after. In these cases, the erroneous positions were interpolated back to the midpoints between the antecedent and posterior positions. Loss of positional data as a result of elevated land surfaces between the boat and the master station never occurred during the Lago Yahuecas survey and no loss of data occurred. Elevation and depth contours were drawn at 0.5-meter intervals from the deepest part of the reservoir up to the reservoir shoreline.

\section{Quality checks of the positional data collected} during the bathymetric survey indicate that 90 percent of the positions calculated were within 2 meters of their true geographic positions. To comply with USGS national mapping standards, no more than 10 percent of identifiable points on a map will have a horizontal error greater than 0.5 millimeter translated by the map scale; for example, 90 percent of the points on a 1:20,000 scale map are within 10 meters of their plotted position on the map. This would indicate that the sounding data collected during this study could be used to plot positions on a map at a scale of 1:4,000; however, the precision is not quantifiable in the area between the cross sections.

The bathymetric data of 1997 conformed well with the shoreline obtained from the topographic map and these were combined into one coverage (plate 1). The contour lines were then converted into a surface model by creating a triangulated irregular network. The TIN models the lake bottom as thousands of adjoining triangles with $\mathrm{x}, \mathrm{y}$, and $\mathrm{z}$ coordinates assigned to all vertices. The reservoir volume was then calculated at incremental pool elevations of 1 meter to develop a stage-storage capacity curve. A contour map and TIN surface model of the original 1956 reservoir bottom was also produced using a 1:20,000 scale topographic map (plate 2).

The resolution of the shorelines and depth contours derived from the 1956 topography is different than that of the 1997 bathymetric map. The original topography from 1956 had a contour interval of 10 meters, whereas the 1997 bathymetric map has a contour interval of 0.5 meter. Additional contour lines were added to the 1956 topography to smooth the computer generated surface of the 1956 lake bottom.

Selected cross sections describing the 1956 and 1997 TIN's are compared in figure 5 to show the amount of sediment that has been deposited since the reservoir was impounded. Also, the longitudinal profiles generated from the 1997 and 1956 TIN's were compared to verify that the model sections accurately reflect the lake bottom. The comparison of the longitudinal profiles across the 1956 and 1997 TIN surface models is shown in figure 6 .

Using the TIN models, the flooded areas at the spillway elevation of 448.36 meters above mean sea level was calculated to be 0.23 and 0.22 square kilometers for 1956 and 1997, respectively, a difference of only 4 percent. The most significant shoreline changes observed were the cut and fill operation at the dam and the infilling of the proximal and middle parts of the reservoir. The overall match between the original and current lake bottom is satisfactory for documenting where and how much sediment has deposited in the reservoir. 

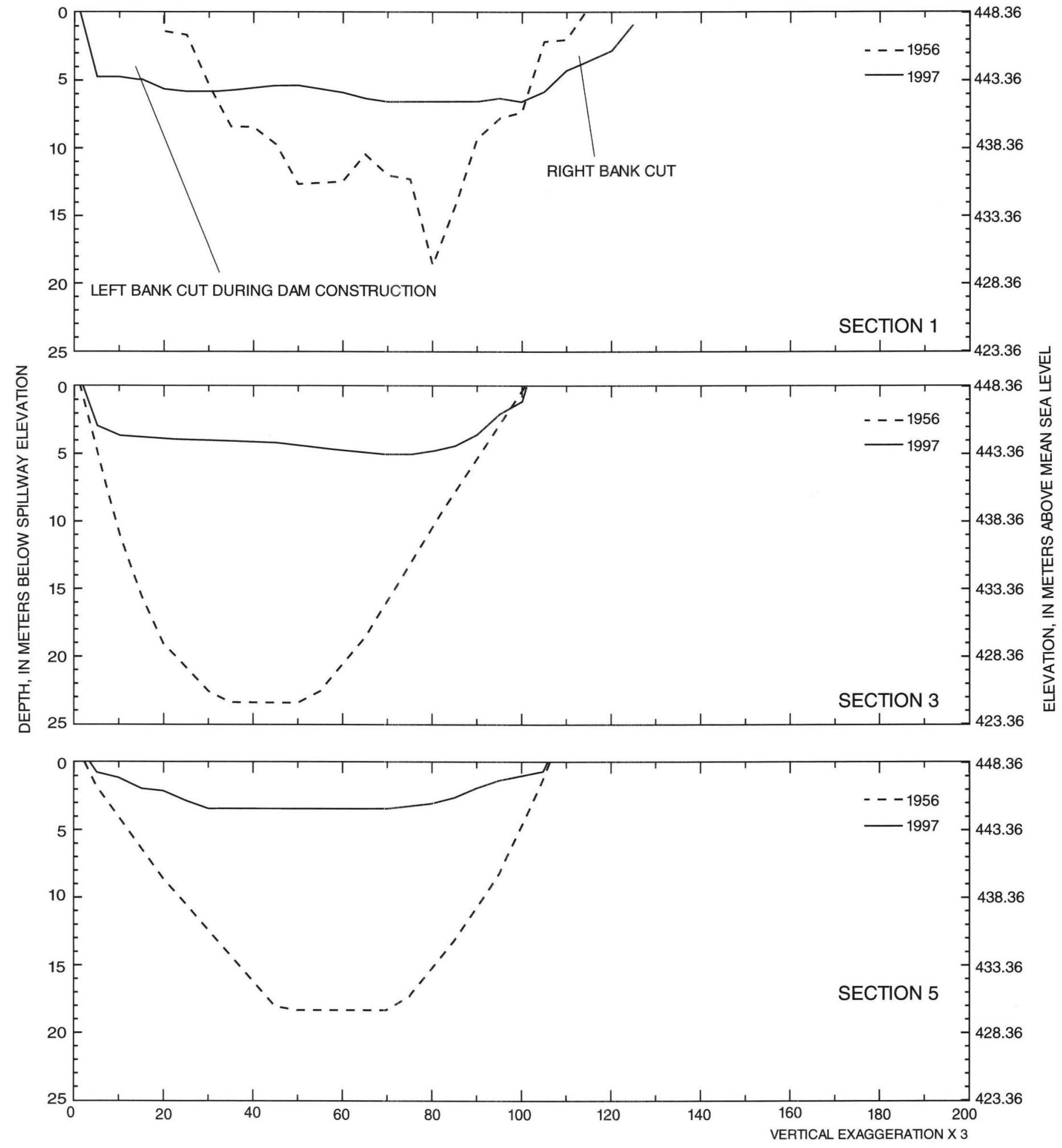

DISTANCE FROM LEFT BANK, IN METERS

Figure 5. Selected cross sections generated from TIN surface model of Lago Yahuecas, Puerto Rico, for 1956 and 1997. Cross sections are oriented in the downstream direction. Refer to figure 2 for the location of each cross section. 

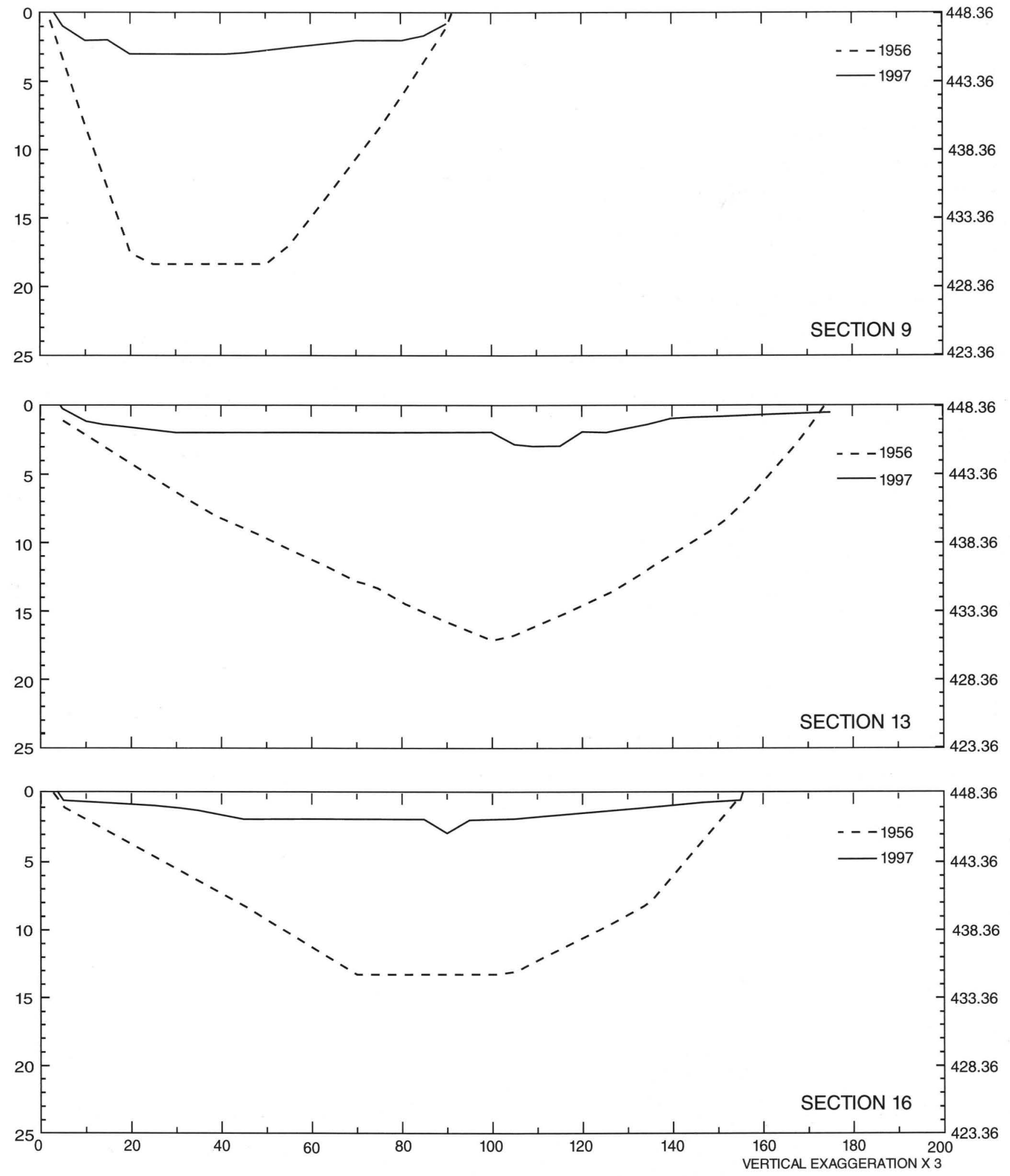

DISTANCE FROM LEFT BANK, IN METERS

Figure 5. Selected cross sections generated from TIN surface model of Lago Yahuecas, Puerto Rico, for 1956 and 1997-Continued. Cross sections are oriented in the downstream direction. Refer to figure 2 for the location of each cross section. 

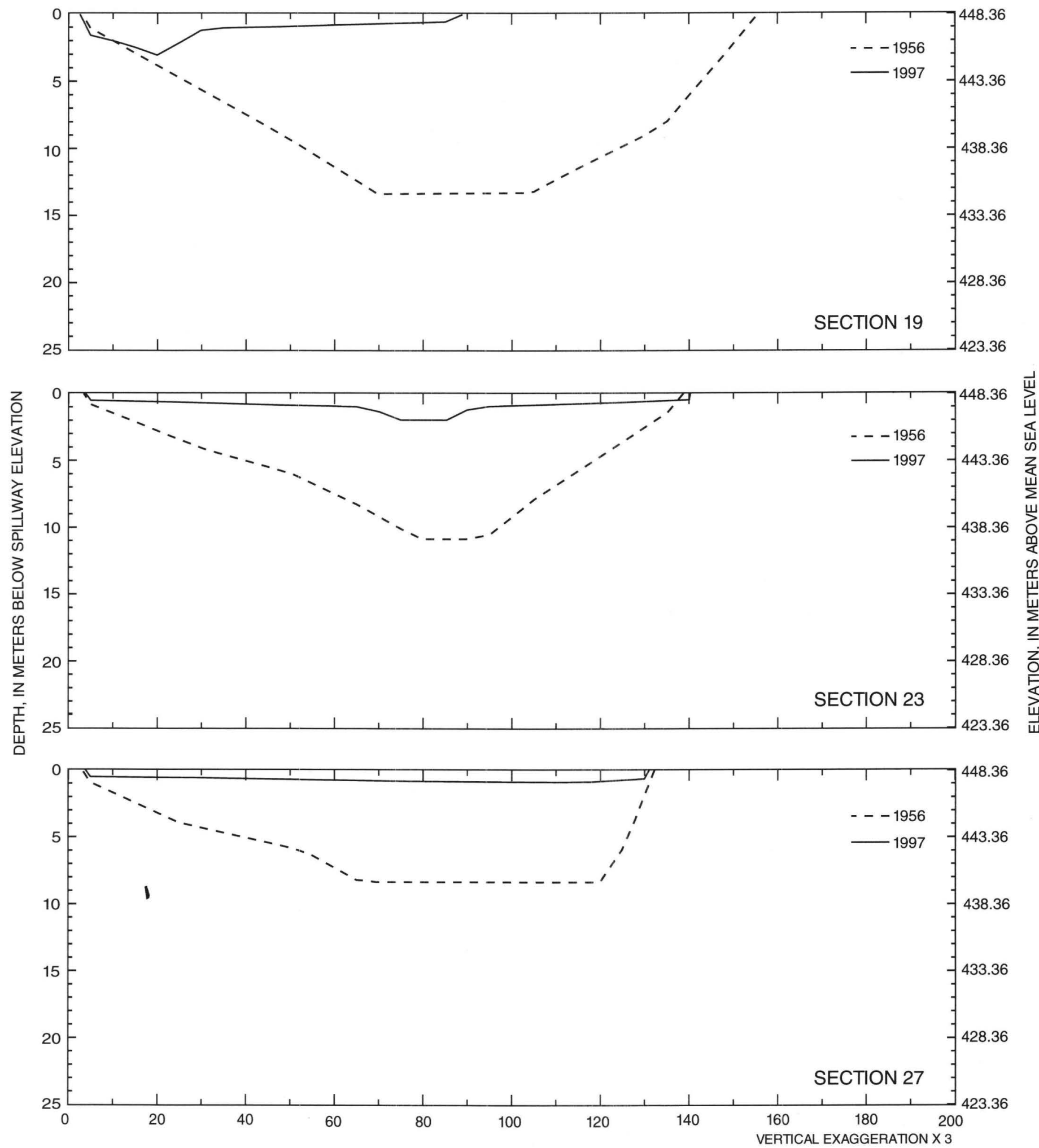

DISTANCE FROM LEFT BANK, IN METERS

Figure 5. Selected cross sections generated from TIN surface model of Lago Yahuecas, Puerto Rico, for 1956 and 1997-Continued. Cross sections are oriented in the downstream direction. Refer to figure 2 for the location of each cross section. 


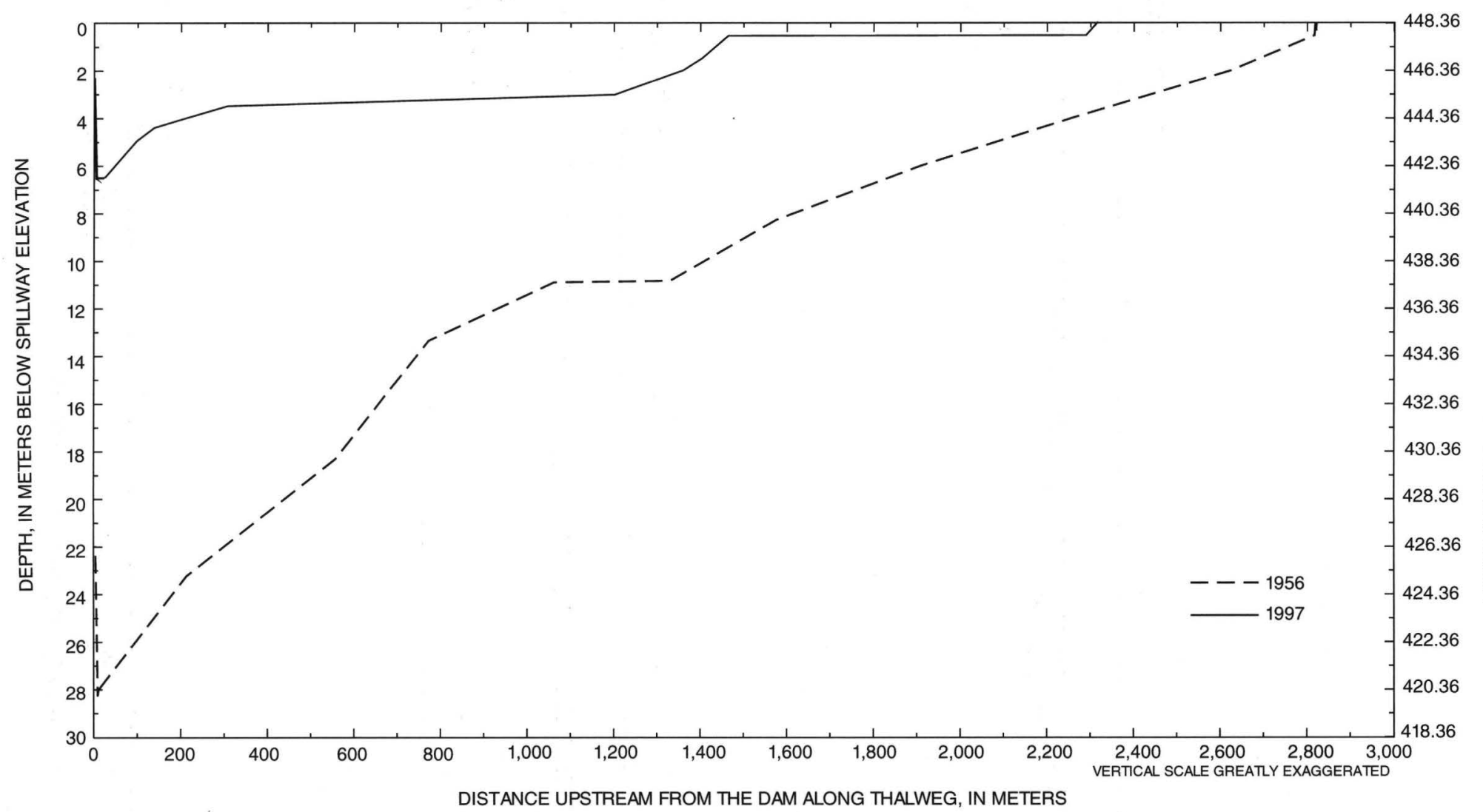

Figure 6. Comparison of Iongitudinal profiles for 1956 and 1997 along the thalweg of Lago Yahuecas, Puerto Rico. 
The original volume (at an elevation of 448.36 meters above mean sea level) was calculated to be 1.76 million cubic meters using the TIN of the 1956 topography. Volume calculations can vary up to 10 percent for small reservoirs depending on the method and the quantity and orientation of the ranges (Heinemann and Dvorak, 1963). For this study, GIS algorithms were used to calculate volumes of the surface models represented by the 1956 and the 1997 contour maps (Environmental Systems Research Institute, Inc., 1992).

\section{SEDIMENT YIELD}

To estimate the annual sediment yield of the drainage basin, sediment cores were sampled at various pre-selected locations (fig. 2). One to 3-meter cores were recovered from the deepest part of seven cross sections and one at the inlet structure for the Yahuecas-Guayo tunnel using a modified Davis-Doyle sediment corer. These cores were then divided into subsamples every 25 centimeters for a bulk density determination. The samples were then labeled and sealed in tared plastic containers to be analyzed in the laboratory. Samples were dried at 105 degrees Celsius to determine their dry bulk density. Table 2 summarizes the results of the laboratory analysis.

The average dry bulk density of all of the sediment samples was 0.98 gram per cubic centimeter. This reveals a high dry bulk density indicating that the sampled cores consisted mostly of coarse material. Unlike most of the bigger and deeper reservoirs where coarse material rarely reaches the dam, in Lago Yahuecas coarse material was found in the vicinity of the dam. This is the result of the high water velocities created when the channel becomes more shallow and narrow as flood events accumulate bed load and fine sediments in the channel. During flood events, when the majority of sediment is transported, Lago Yahuecas behaves like a stream channel instead of a reservoir.

The amount of sediment accumulated in the reservoir multiplied by the dry bulk density of the sediments gives the total amount of solid material contributed by the reservoir basin since impoundment. Based on the 45.71 square kilometers drainage area of the reservoir, the sediment yield of the basin was computed to be 757 megagrams per square kilometer per year.

Table 2. Summary of the average dry bulk density of the sediment cores collected on Lago Yahuecas, Puerto Rico, March 1997

[The values represent the average of 25 centimeter subsamples for each site]

\begin{tabular}{ccc}
\hline Site name & $\begin{array}{c}\text { Distance from the dam, } \\
\text { in meters }\end{array}$ & $\begin{array}{c}\text { Average dry bulk density, } \\
\text { in grams per cubic centimeter }\end{array}$ \\
\hline YA-1 & 50 & 0.82 \\
YA-2 & 200 & 0.95 \\
YA-3 & 400 & 0.94 \\
YA-4 & 600 & 1.20 \\
YA-5 & 850 & 0.87 \\
YA-6 & 1,150 & 0.98 \\
YA-7 & 1,400 & 1.34 \\
YA-8 & 90 & 0.72 \\
Average & & 0.98 \\
\hline
\end{tabular}




\section{ACTUAL CAPACITY AND SEDIMENT ACCUMULATION}

The Lago Yahuecas storage capacity has decreased from 1.76 million cubic meters in 1956 to 0.33 million cubic meters in 1997. This represents a reduction of 81 percent from the original capacity. The annual capacity loss was estimated to be about 34,878 cubic meters per year which represents 2 percent per year. These values were computed using a 1956 topographic quadrangle map combined with a 1997 bathymetric survey. Stage-storage curves were produced for both the 1956 and the 1997 TIN and are shown in figure 7. The storage volume for a given stage were calculated at pool elevations in 1-meter increments from the minimum to maximum elevations of each TIN. Data for prior and current sedimentation surveys of Lago Yahuecas are summarized in table 3 .

Sediment accumulation in Lago Yahuecas is extensive as shown in figures 5 and 6. Sediment deposits range from 13 to 19 meters in thickness near the dam and from 9 to 15 meters in other parts of the reservoir. A thick layer of sediment has raised the bottom of the reservoir to a point that the trapping efficiency of the reservoir is expected to be low.

The trapping efficiency of the reservoir was estimated by the capacity/inflow ratio described by Brune (1953). Since there is no stream gaging station on the Río Blanco above Lago Yahuecas to measure the inflow to the reservoir, the runoff was estimated by using the mean annual rainfall of 2,290 millimeters (Calvesbert, 1970) and the runoff/rainfall ratio of 0.45 (Giusti and López, 1967) for this particular basin. Thus, the mean annual runoff was calculated to be 1,030 millimeters or equivalent to 1.03 million cubic meters per square kilometer.

Based on the 45.17-square kilometer contributing drainage area of Lago Yahuecas, the average annual runoff reaching Lago Yahuecas was estimated to be 46.52 million cubic meters. Using the capacity/inflow ratio described by Brune's (1953) curve, (330,000/46,520,000 for Lago Yahuecas), the trapping efficiency of the reservoir was estimated to be about 35 percent. Although the reservoir is expected to have a short life (approximately 10 years) as a result of its large average storage capacity loss of 34,878 cubic meters per year, the actual time until the reservoir is completely filled will probably be somewhat longer as the trapping efficiency continues to decrease.

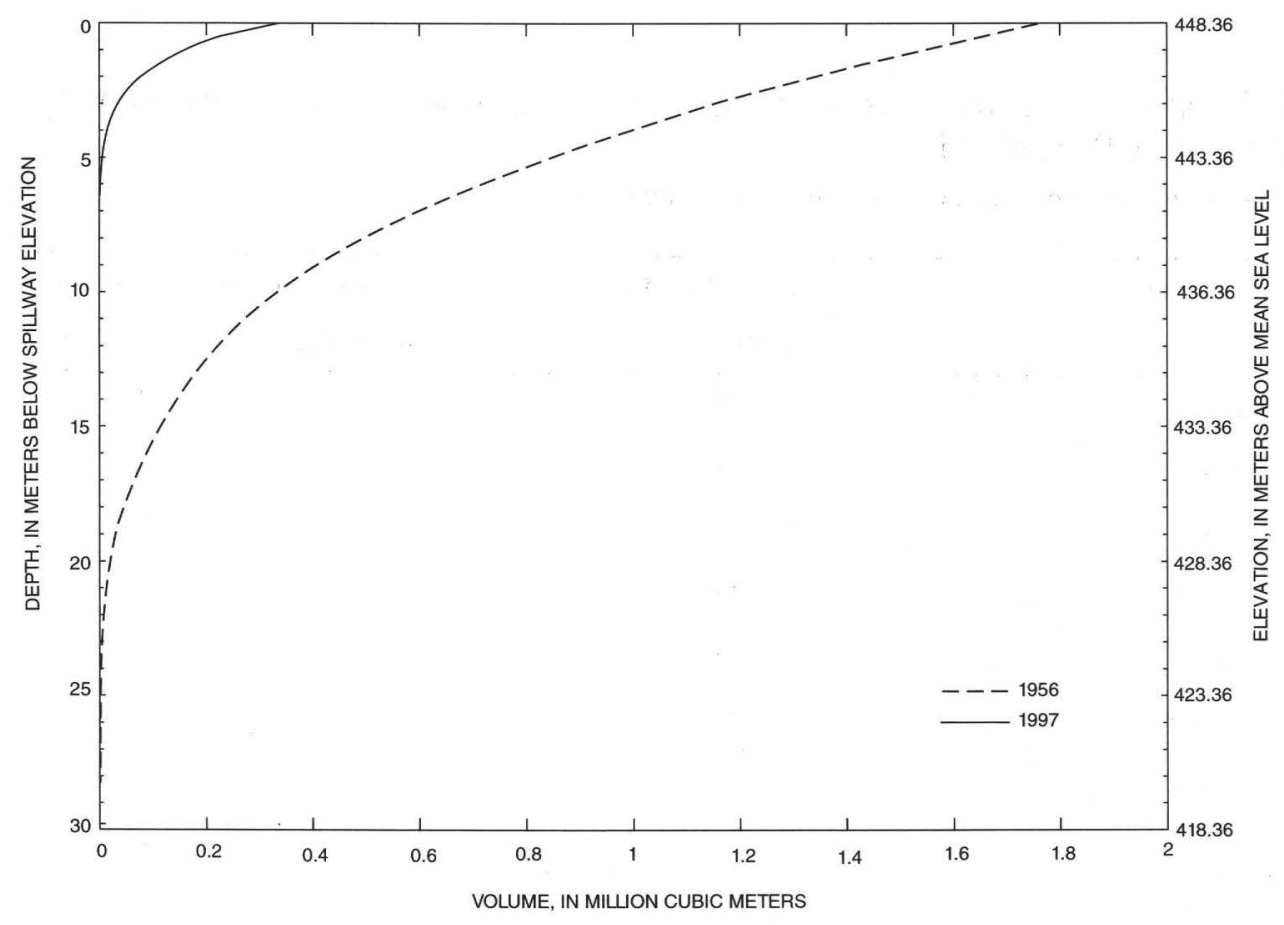

Figure 7. The relation between pool elevation and volume derived from the 1956 and 1997 TIN surface models of Lago Yahuecas, Puerto Rico. 
Table 3. Summary data for prior and current sedimentation surveys of Lago Yahuecas, Puerto Rico [Elevation datum, National Geodetic Vertical Datum 1929; TIN, triangulated irregular network]

\begin{tabular}{llc}
\hline & 1956 & 1997 \\
\hline $\begin{array}{l}\text { Capacity (in million cubic meters) at spillway elevation of } 448.36 \\
\text { meters }\end{array}$ & 11.76 & 0.33 \\
$\begin{array}{l}\text { Live storage in million cubic meters (above sluiceway elevation of } \\
429.46 \text { meters) }\end{array}$ & 1.73 & 0.33 \\
$\begin{array}{l}\text { Dead storage in million cubic meters (below sluiceway elevation } \\
429.46 \text { meters) }\end{array}$ & .03 & 41 \\
$\begin{array}{l}\text { Years since construction } \\
\text { Sediment accumulated } \\
\text { (millions of cubic meters) }\end{array}$ & 0 & 1.43 \\
$\begin{array}{l}\text { Storage loss (percent) } \\
\text { Annual loss of capacity (cubic meters) } \\
\text { Annual loss of capacity (percent) } \\
\text { Approximate year that reservoir would fill with sediment }{ }^{2}\end{array}$ & 0 & 81 \\
\hline
\end{tabular}

${ }^{1}$ Original capacity using the TIN model of the 1956 preimpoundment topography.

${ }^{2}$ Assuming that the reservoir would continue filling at the long-term sedimentation rate; in reality the reservoir sedimentation rate decreases with time as the reservoir fills with sediment and the trapping efficiency decreases.

\section{REFERENCES}

Brune, G.M., 1953, Trap efficiency of reservoirs: Transactions of the American Geophysical Union, v. 34 , no. 3, p. 407-418.

Calvesbert, R.J., 1970, Climate of Puerto Rico and U.S. Virgin Islands: U.S. Department of Commerce, Environmental Science Services Administration, $29 \mathrm{p}$.

Environmental Systems Research Institute, Inc., 1992, Surface modeling with TIN, Surface analysis and display: Environmental Systems Research Institute, Inc., Redlands, California, p. 4-1, 6-1.

Giusti, E.V., and López, M.A., 1967, Climate and streamflow of Puerto Rico: Caribbean Journal of Science, v. 7, no. 3-4, September-December 1967, p. $87-93$.
Heinemann, H.G., and Dvorak,V.I., 1963, Improved volumetric survey and computation procedures for small reservoirs: U.S. Department of Agriculture Miscellaneous Publication 970, Symposium 4-Sedimentation in reservoirs, p. 845-856.

Sheda, H.E., and Legas, James, 1968, Condition of concrete dams in Puerto Rico: Section 6, Condition of Lago Yahuecas dam, Puerto Rico: Prepared for Puerto Rico Water Resources Authority, Puerto Rico Aqueduct and Sewer Authority by the U.S. Department of Interior, Bureau of Reclamation, 10 p., 6 pls. 